Ahmed, R. R., Streimikiene, D., Rolle, J-A, \& Duc, P. A. (2020). The COVID-19 Pandemic and the Antecedants for the Impulse Buying Behavior of US Citizens. Journal of Competitiveness, 12(3), 5-27.

https://doi.org/10.7441/joc.2020.03.01

\title{
THE COVID-19 PANDEMIC AND THE ANTECEDANTS FOR THE IMPULSE BUYING BEHAVIOR OF US CITIZENS
}

\author{
- Rizwan Rabeem Abmed, Dalia Streimikiene, Jo-Ann Rolle, Pham Anb \\ Duc
}

\begin{abstract}
In an analysis based on the theory of Fear, this study examines impulse purchase patterns during the COVID-19 Pandemic across major US urban centers. Data from 889 US consumers were collected from leading US cities to evaluate impulse buying behavior fluctuations using SEM-based multivariate approaches to examine the survey statistics. We used COVID-19 as a moderating variable of this impulse purchase behavior. The results confirmed that Fear of a complete lockdown, peers buying, scarcity of essential products on shelves, US stimulus checks, the limited supply of essential goods, and panic buying have had a compelling and affirmative influence on the sharp swings of impulse buying patterns. The findings further confirm that Fear Appeal and social media fake news have had a strong positive impact on impulse buying as mediating factors. Finally, it was concluded that COVID-19 is a significant moderating factor influencing the impulse buying behavior of US citizens. The practical implications suggest that marketers and brand managers should devise novel strategies to enhance their brand's market share to attain a competitive advantage in COVID-19 or similar panic situations in the future. These research findings are essential to comprehend the sharp fluctuations of impulse buying patterns in the current cutthroat competition environment across the US and other parts of the world.
\end{abstract}

Keywords: COVID-19 pandemic, impulse buying behavior, theory of fear, panic buying, SEM-based multivariate approach

JEL Classification: C12, D12, M3

Received: June, 2020

1st Revision: August, 2020

Accepted: August, 2020

\section{INTRODUCTION}

In the first months of 2020, the COVID-19 virus was announced all over the world, with millions of people quarantined to maintain social and physical distancing by mid-March. Since then, lives have been disrupted due to precautions taken to alleviate the COVID-19 Pandemic (Addo et al., 2020). In response to the prolonged imposed isolation and Fears about the future because of the pandemic, consumers have been involved in panic buying for weeks (INSEAD, 2020). This has overloaded fragile supply chains and harmed consumers financially (Crabble, 
2020). The type of purchase pattern is broadly acknowledged in the field of marketing research; a massive amount of academic literature has already been published to ascertain the antecedents of impulse buying behavior. A substantial amount of literature has pointed out that conscious (planned) or subconscious (impulsive) purchase patterns are driven mainly by hedonic (emotional) and utilitarian (practical) stimuli (Leverin \& Liljander, 2006). Several other research studies have declared that motivation, attitude, and identified perceptions are the precursors for consumer behavior, which is significantly influenced by consumer beliefs (Haq \& Abbasi, 2016; Güler, 2014). As previous literature has shown, the influence of utilitarian and hedonic buying serve predominantly as moderators (Koparal \& Çalik, 2015), and mediators (Haq \& Abbasi, 2016). However, other studies such as Bergel \& Brock (2019) have demonstrated that these factors are direct and independent variables that significantly influence buying patterns. Nevertheless, considerable literature has fixated on the positive characteristics of utilitarian and hedonic drives, but has not dealt with the external antecedents. Most previous academic studies have focused on purchase decisions linked with piece of mind, pleasure, and other positive emotions. According to Mogilner et al. (2012) and Foroughi et al. (2013), these factors are significant influencers in making an impulse buying decision. However, some studies have concentrated on the negative impact of hedonic attitudes on purchase decisions. According to Boutsouki (2019), only the perceptions and assumptions of economic calamities emerge which cause negative hedonic drives that contribute to purchase decisions. For the successful management of companies and ensuring their competitiveness, it is important to know consumer behavior patterns and their drivers (Khan et al, 2019; Čepel, 2019; Dobrovič et al., 2019; Dvorský et al., 2019).

Governments in several US states have revised their guidelines for social distancing, as they anticipate the level of severity remaining in an upsurge as the lethal COVID-19 pandemic will further spread across the country (Iyer et al., 2020; Numerator Intelligence, 2020). To comprehend the real human behavior, this study examines beyond the normal behavioral, subconscious, and emotional prejudices that motivate social perceptions and behavior (Adam, 2020). According to Oberst et al. (2017), most behavioral biases start in the areas of the brain's fast thinking which is also responsible for human emotions. According to Crabble (2020) and Addo et al. (2020), the round-the-clock electronic and print media coverage, often featuring emergency news concerning fatalities of COVID-19 further spark the emotional state of Fear, and people have been placed into an endurance approach. Thus in this research we have employed the theory of Fear Appeal. We have laid down the foundations for this study on this almost forgotten theory. Nevertheless, we propose the contradictory of what has directed current literature; we concentrate on a purchase evaluation of essential items, such as buying out of utilitarian (necessity) and hedonism (fear) (Wegmann et al., 2017; Abel et al., 2016). The undertaken study examines the antecedents and dynamics of impulse buying patterns in the rise of COVID-19 and assessed the impact of US citizen impulse purchasing behavior during this situation based on Fear (Iyer et al., 2020; Limaye et al., 2020). Using the theory of Fear Appeal, we evaluate how US citizens behave in supermarkets, and what are the rationales behind impulse buying behavior.

The remainder of the paper comprises a theoretical background and hypotheses formulation in section two, with the research objective, methodology and data provided in section three. Results and discussion are located in section four, with the conclusion in section five. 


\section{THEORETICAL BACKGROUND AND HYPOTHESES DEVELOPMENT}

\subsection{Impulse Buying Behavior}

Scholars have been focusing on consumer impulse buying for several decades, providing a long history of definition formations. According to Rajan (2020), Liu et al. (2019), and Güler (2014), the term is associated with naive, immature, ignorant, and intellectual deficiencies. Parsad (2020) characterized an impulse purchase pattern, as impulse buying occurs when consumers experience an expected, intense, and continual impulse to buy something immediately. Nevertheless, it cannot be labeled as involving the substantial aspect of pioneering hedonism, which is a precursor to enacting purchases as impulses. Similarly, Suryaningsih (2020) and Zafar et al. (2019) found that impulse purchases involve an investment made through due to a given motivation in which the decision to purchase something does not depend on profound thought processes. Impulse buying can be induced by external stimuli. Still, according to Addo et al. (2020), not only external stimuli are involved, but also internal stimuli related to personal emotions. Matteo et al. (2020) added that impulse buying could help people deal with low confidence, negative emotional states and negative mental thinking. Thus, in the context of the fear-inducing COVID-19 phenomenon, impulse buying behavior has significantly increased across the United States and other parts of the world (Wiranata \& Hananto, 2020; Kim, 2020; Addo et al., 2020; Matteo et al., 2020).

\subsection{Fear of a Complete Lockdown}

COVID-19 has had an extensive frightening effect that has terrified people from China to the United States, with anxious citizens engaged in panic buying as well as indulging in impulse buying due to partial and complete lockdowns (Matteo et al., 2020; Addo et al., 2020). Thus, due to the stress induced, citizens have been ordered to take extra precautions against the spread of COVID-19 in the form of partial or complete lockdown across the world (Zhang et al., 2019). The WHO has announced the COVID-19 outbreak as a pandemic, which compelled several countries, including the United States, towards their final decisions to announce lockdowns in the second week of March (Crabble, 2020; Iyer et al., 2020). According to Addo et al. (2020), COVID-19 is more dangerous than the flu in terms of contagiousness, and the death rate is 20 to 30 times greater than the flu. Therefore, not only has the US government imposed a lockdown, but also people have put themselves in self-isolation. Thus the shortage of workers and managers who are normally heavily involved in stocking essential items have also triggered impulse buying patterns. The WHO has also recommended remaining in isolation, and several countries have taken the step of a partial or complete lockdown, including the US, Canada, Italy, China, Spain, France, and other European countries (Kim \& Su, 2020; Crabble, 2020). Hence, the following hypothesis is framed based on the literature:

H1: The fear of a complete lockdown has had a positive and significant impact on impulse buying behavior. 


\subsection{Peers Buying}

Buying patterns greatly influence each other across populations. Human purchase behavior is the outcome of acquiring information, attitudes and behaviors from other individuals in peerto-peer social interaction in the form of trends and fashions (De Veirman et al., 2017). Since companies attempt to rise to these challenges, they ascertain these changes consumer attitudes and behavior (Kim, 2020). These challenges are conditioned by 1) the companies response to the problem, and 2) changing customer habits and attitudes that will drive others (Bergel \& Brock, 2019). Similarly, the novel coronavirus has produced the same peer-buying pattern in Europe, Canada, and the United States (Suryaningsih, 2020). People were inclined towards impulse buying behavior due to the negative and positive word of mouth of peers, watching the buying of neighbors and peers (Addo et al., 2020; Matteo et al., 2020). In a condition where the incitement info desires to be mirrored upon, consumers' emotional state is also combined into the administering of the appeal that is hugely driven by the apparent inspiration of the individuals around them (Crabble, 2020; Zhang et al., 2019). According to Kim \& Su (2020), consumers adapt to anticipations of peers about buying decisions and acquire product suitability by perceiving the buying behavior of other people. Similarly, in a situation like COVID-19, people follow the purchase pattern of peers in online and offline purchases. Hence, the following hypothesis is framed based on literature:

H2: Peers buying has a positive and significant impact on impulse buying behavior.

\subsection{Scarcity of Essential Products in Shelves}

According to Crabble (2020) and Suryaningsih (2020), stepping into the superstore, and watching counter lines in early days of COVID-19, they were three times their usual queues and watched this condition, everybody realized that they should also stock up the essential items. In the superstores, the buyers at the frozen food section, or pasta aisle, and then returning to the corner in shockwave to locate rows and rows of empty shelves (CNN, 2020). According to Crabble (2020), and Kim \& Su (2020), as the news of COVID-19 has grasped the attention of the world, the supermarkets, usually overflowing with every essential item, but rapidly been gone by consumers panic purchase water, frozen food, bread, toilet papers, and other grocery items. The circulated images of empty shelves and long queues of consumers on mainstream and social media further tempted to the people for impulsive buying to purchase and stock up essential and non-essential items through online and offline stores (Iyer et al., 2020; Addo et al., 2020). Even in April, people were involved in intense impulse buying, which further aggravated the condition and dried up the shelves of supermarkets (CNN, 2020). Thus, the following hypothesis is framed based on literature:

H3: The scarcity of essential products on shelves has a positive and significant impact on impulse buying behavior.

\subsection{The Limited Supply of Essential Goods}

The COVID-19 pandemic has spread quickly, creating unexpected panic buying, and people involved intensely in impulse buying purchases. The demand for essential items has increased several folds, and companies were unable to meet the sudden surge of consumer demand. Thus, this 
leads to the supply chain disruption and superstore-faced shortages of essential goods, leading to further panic in consumers (Kim \& Su, 2020; Rajan, 2020). According to Addo et al. (2020), and Kim (2020), the outbreak of COVID-19 has created both supply and demand shocks rumbling across the United States and all over the world. According to Guitton (2020), and Crabble (2020), a misapprehension about the condition of the food and other essential items supply chain eached to its breaking point in terms of anxiousness. After the COVID-19 pandemic outbreak, the food items inventory split between superstores and restaurants. Due to panic buying, the demand for essential items further increased, which also disrupted the overall supply chain process of crucial goods $(\mathrm{CNN}, 2020)$. Therefore, in this situation, the anxiety of consumers aggravated, and they tilted more towards the impulse buying behavior (Kim 2020). Hence, the following hypothesis is framed based on literature:

H4: The limited supply of essential goods has a positive and significant impact on impulse buying behavior.

\subsection{Panic Buying}

According to the report of Numerator Intelligence (2020), most of the department stores of US cities are described as a rapid run twisted into a nightmare, steering long queues of hundreds of buyers stocking up during the outbreak of COVID-19 when the US government declared the state of emergency after the death of first COVID-19 patient. "For the most part, people were understanding and relatively calm (Suryaningsih, 2020; CNN, 2020), but patience was starting to grow thin". Consumers have a long queue with loaded trolleys with toilet paper, sanitizers, bottled water, milk, and other grocery items that were observed across the United States due to the Fear of COVID-19 (Crabble, 2020). People were involved in panic buying across the USA because of Fear, and they were more indulging in impulse buying behavior (Przybylski et al., 2013; Abel et al., 2016; Liu et al., 2019). The panic buying is observed in the US cities and seen in Canada, where the people even got panicked and did impulse buying of grocery and other essential and non-essential items (Iyer et al., 2020). This type of panic and impulse buying behavior can make shortages worse (Zafar et al., 2019; Bergel \& Brock, 2019). Hence, the following hypothesis is framed based on literature:

H5: Panic buying has a positive and significant impact on impulse buying behavior.

\subsection{The US Stimulus Checks}

The US government has announced a financial stimulus package that vows to assist in easing the financial burden of millions of Americans. Thus, US citizens have been receiving stimulus checks since April 2020 (CNN, 2020). A survey was conducted by Numerator Intelligence (2020) and asked the consumers how they would spend this money. Most of the consumers have answered that they will pay their bills, buy groceries, and other essential items. However, some middle-class shoppers vowed to save this money for hard times (Numerator Intelligence, 2020). People were more tangled in impulse purchases because of the unexpected benefit of the US stimulus checks; the average family received $\$ 3,000$ to $\$ 4,000$ depending on the family members (Crabble, 2020). People have spent this money on food (grocery items), sanitary, beer, and lottery; thus, most of the purchases belong to the non-essential items because of impulse buying 
behavior (Addo et al., 2020). People have spent stimulus checks in two to three weeks, mostly in non-essential items, because easy money always is the right trigger for impulse buying behavior (CNN, 2020; Matteo et al., 2020). Hence, the following hypothesis is framed based on literature: H6: The US stimulus checks have a positive and significant impact on impulse buying behavior.

\subsection{Fear Appeal}

According to Addo et al. (2020), and Wegmann et al. (2017), the Fear grew as an instrument to safeguard from the situation in which life is endangered. Nothing is more important than survival; thus, the evolutionary supremacy of the human brain's circuitry of Fear activates. The brain's Fear circuitry is dominating than the brain's reasoning faculties (Witte \& Allen, 2000). According to Lai et al. (2016), and Riordan et al. (2018), the Fear Appeal comprises three significant conceptions: perceived efficacy, threat, and Fear. The theory of Fear Appeal is applied in marketing and advertising campaigns, especially in health insurance, life insurance, and product safety features. Similarly, after the certainty of lethal COVID-19, the Fear factor fueled by utilitarian and hedonic motivations (Crabble, 2020; Kim, 2020). However, the theory of Fear appeal has a subjugated tool in marketing research, but it was not frequently used in recent times (Witte \& Allen, 2000). According to Wegmann et al. (2017), the Fear Appeal is an important communication devised to transfer realities or to frighten people by disliking or amplifying awful consequences of ignoring certain cautiousness. The Fear Appeal can be categorized into Fear control, and danger control, the Fear control revolves around emotional reactions caused by risk. However, danger control directs adaptive behavior to avoid it (Przybylski et al., 2013). However, there are no outward signs of remedial and altering the COVID-19 pandemic, people have to deal with, or prevent, and counter it (Wegmann et al., 2017). Thus, the people responded in several ways, they buy essential items and did overstocking at their homes, isolate themselves from the community, they intensely involved in buying grocery, beer, sanitizers, and toilet papers (Addo et al., 2020). Thus, several studies suggested that the Fear appeal is an important mediating variable during the impulse purchase behavior (Iyer et al., 2020; Addo et al., 2020; Przybylski et al., 2013). Hence, we have framed the following hypotheses:

H7A: Fear appeal mediates between Fear of complete lockdown and impulse buying behavior.

H7B: Fear appeal mediates between peers buying and impulse buying behavior.

H7C: Fear appeal mediates between scarcity of essential products in shelves and impulse buying behavior.

H7D: Fear appeal mediates between the limited supply of essential goods and impulse buying behavior.

H7E: Fear appeal mediates between panic buying and impulse buying behavior.

H7F: Fear appeal mediates between the US stimulus checks and impulse buying behavior.

\subsection{Social Media Fake News}

Due to the highly contagious range of COVID-19 and physical distancing, people have restricted to their homes. Therefore, they heavily relay on social media news. The use of smartphones has now become a necessity, and people are surfing different social media sites such as Facebook, 
Whatsapp, Instagram, and Twitter for entertainment and news purposes (Ahmed et al., 2020). Thus, social media has become the primary source of human interaction and information sharing regarding COVID-19 (Addo et al., 2020). Therefore, this misinformation damages the effective retorts to COVID-19, and people feel more anxiety and Fear during the deadly COVID-19 pandemic (Limaye et al., 2020). In this scenario, the credibility and acceptability of social media news have been undermined. Thus, different digital media channels have contributed significantly to misinformation (Zhang et al., 2019). When the first case of COVID-19 was reported, the traditional and social media have started to spread a broad range of misleading information. Hence, the WHO has termed it Infomedic, which means "an excessive amount of misinformation, disinformation, and rumors that make it difficult to identify the reliable sources of information" (Garrett, 2020). The miss-leading information also affected the general consumers and the buying patterns of US citizens and get panic. They tilted more towards the impulse buying for essential and non-essential goods (Crabble, 2020). We have framed the following hypotheses by taking social media fake news as a mediating variable:

H8A: Social media fake news mediates between Fear of complete lockdown and impulse buying behavior.

H8B: Social media fake news mediates between peers buying and impulse buying behavior.

H8C: Social media fake news mediates between the scarcity of essential products in shelves and impulse buying behavior.

H8D: Social media fake news mediates between the limited supply of essential goods and impulse buying behavior.

H8E: Social media fake news mediates between panic buying and impulse buying behavior.

H8F: Social media fake news mediates between the US stimulus checks and impulse buying behavior.

\subsection{COVID-19 Pandemic}

Besides the epidemiology, the spread of deadly COVID-19 has broader consequences, not only on the fluctuations of the economy, but also it impacted the consumer purchase decision across the United States, and other parts of the World (Addo et al., 2020). The COVID-19 phenomenon altered US citizens' buying patterns due to the Fear and psychological factors that would have a long-lasting impact on the years (Crabbe, 2020). Among employed survey participants, spending more time at home seems to lead to impulsive buying behavior (Iyer et al., 2020; Crabbe, 2020). According to Iyer et al. (2020) and Kossman (2016), habitually, this unintended buying is not even for small products, as per the study of CreditCard.com, one out of five US citizens having consumed more than $\$ 1,000$ in impulse buying. Coronavirus had impacted citizens consumers' shopping behavior in the United States, and due to the COVID-19 pandemic, consumers skewed towards impulse buying behavior (Addo et al., 2020). Thus, it is established that COVID-19 has impacted significantly, and people are more involved in impulse buying in the United States (Garrett, 2020). Hence, we have framed the following hypotheses by keeping in view the COVID-19 pandemic as a moderating variable: 
H9A: The COVID-19 pandemic moderates between Fear of complete lockdown and impulse buying behavior.

H9B: The COVID-19 pandemic moderates between peers buying and impulse buying behavior.

H9C: The COVID-19 pandemic moderates between the scarcity of essential products in shelves and impulse buying behavior.

H9D: The COVID-19 pandemic moderates between the limited supply of essential goods and impulse buying behavior.

H9E: The COVID-19 pandemic moderates between panic buying and impulse buying behavior. H9F: The COVID-19 pandemic moderates between the US stimulus checks and impulse buying behavior.

\subsection{Conceptual and Theoretical Model}

The previous literature helps comprehend and integrate the theory of Fear with the antecedents of impulse buying, and construct a novel model with mediators and COVID-19 as a moderator to analyze the impulse buying behavior of the US citizens. The undertaken study examines the modified conceptual and theoretical framework that is developed based on previous literature. This research evaluates and substantiates the existing literature and augments the current knowledge by providing a novel model, as demonstrated by Figure 1.

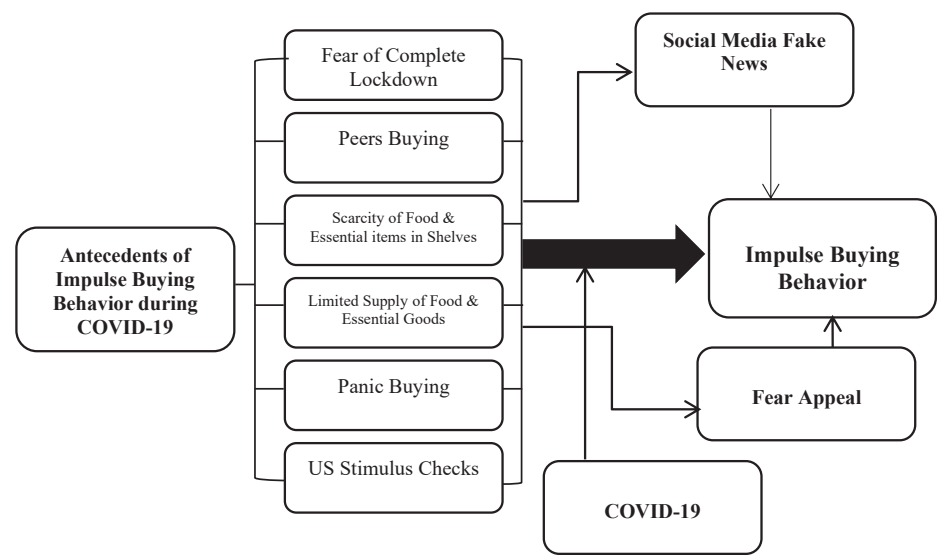

Fig. 1 - Conceptual and Theoretical Modified Model. Source: own research

\section{RESEARCH OBJECTIVE, METHODOLOGY, AND DATA}

\subsection{Objective of this research}

The undertaken study aims to examine the impulse purchase pattern during the COVID-19 Pandemic across the major US urban centers founded based on the theory of Fear. The undertaken study focuses on the imperative connotation amid the precursors such as Fear of complete lock- 
down, peers buying, scarcity of essential products in shelves, limited supply of essential goods, panic buying, and the US stimulus checks. We considered COVID-19 as a moderating variable and examines the impulse buying behavior pattern due to the COVID-19 pandemic in the US citizens. Besides, the antecedents and moderating variable, we also incorporated two important mediating variables such as Fear appeal and social media fake news, and evaluate the impact of mediation between independent variables and impulse buying behavior. The undertaken study has significant theoretical and practical implications. The findings of this research provide necessary ingredients and directions to future researchers to replicate their studies in diverse paradigms to understand the dynamics of impulse buying behavior in natural catastrophes and crises.

\subsection{Research Design and Measurement Scales}

The undertaken study is quantitative and cross-sectional; we developed a modified questionnaire from previous studies. The modified items of impulse buying behavior have been taken from previous studies (Rajan, 2020; Suryaningsih, 2020; Addo et al., 2020; Boutsouki, 2019; Zafar et al., 2019; Liu et al., 2019; Güler, 2014; Haq \& Abbasi, 2016). The modified items for Fear appeal and social media fake news were considered from previous literature (Limaye et al., 2020; Zhang et al., 2019). The items for the COVID-19 factor were developed and adapted from previous literature (Matteo et al., 2020; Liu et al., 2019; Addo et al., 2020). However, the items for antecedents of impulse buying behavior such as Fear of complete lockdown, peers buying, scarcity of essential products in shelves, limited supply of essential goods, panic buying, and US stimulus checks were considered from published reports and studies (Crabble, 2020; Addo et al., 2020; Rajan, 2020; Zafar et al., 2019; Bergel \& Brock, 2019; Zhang et al., 2019; Allon \& Bassamboo, 2011; De Veirman et al., 2017). However, we have provided a link to the questionnaire at the end of the paper.

\subsection{Sampling Strategy and Data Collection}

The overall sampling frame for this research is the population of US consumers from the major cities of the United States, for instance, the Washington DC, New Jersey, New York, Chicago, and Virginia. Since we covered major metropolitan cities in the US, therefore, the collected sample is the best representative for the US citizens. Since the population is unknown for the undertaken study, we used a purposive sampling technique for selecting a sample. We used both online and offline methods. The US consumers' responses were taken through the mall-intercept procedure through recording gadgets due to the timesaving and minimal physical exposure with the consumers. The self-administered questionnaire data of 580 consumers were collected from March 5, 2020 to April 3, 2020 when people were less sensitive, and they did not hesitate to talk. However, the rest of the 309 respondents have recorded their insight through online social media from April 4, 2020 to May 5, 2020. Initially, we received 950 responses from US consumers, both offline and online together. We received 889 questionnaires that were completely responded and fulfilled the undertaken study's requirements.

\subsection{Data Analyses and Estimations Techniques}

The undertaken study employed an SEM-based multivariate technique for the collected respons- 
es, for instance, exploratory factor analysis (EFA) for the suitability and retention of adapted constructs and items. This research also employed the confirmatory factor analysis (CFA) to evaluate the items and constructs that have already been used in previous models (Ahmed et al., 2020; Hair et al., 2010). The CFA approach further confirms modified constructs and items, which also fit in the hypothesized structural and measurement models that are used for the current research (Hair et al., 2010; Byrne, 2009). This research also used descriptive statistics to examine the essential characteristics of constructs, such as standard deviation, mean, Kurtosis, and skewness. The values of standard deviation, skewness, and Kurtosis determined the normality of the data essential to employing the SEM-based multivariate approach (Ahmed et al., 2019; Huang et al., 2004). In the EFA technique, Kaiser Meyer Olkin (KMO) and Bartlett's approaches are incorporated for the data suitability and sample adequacy. Total variance explained further substantiated reliability and retention of constructs. Similarly, in EFA, the rotated component matrix generated the factor loadings, composite reliabilities, and average variance extracted for the reliabilities and validities of items and constructs. The conditional process modeling has also been employed to examine the hypothesized direct and indirect (mediation \& moderation) association of constructs (Hayes \& Rockwood 2020).

\subsection{Demographic Analyses}

In terms of demographic statistics, 388 (43.6\%) respondents were male, and 501 (56.4\%) responses were collected from females. Concerning their marital status, we had 350 (39.4\%) responses from the single ones. However, $303(34.2 \%)$ responses were taken from the married ones, and the rest of $226(25.4 \%)$ respondents were divorced. Our data consists of $317(35.7 \%)$ respondents that had an age bracket of (20-30) years, 201 (22.6\%) respondents were (30-40) years age bracket. However, $122(13.7 \%)$ respondents were taken from the age bracket of (40-50) years, we have taken 140 (15.7\%) from the age bracket of (50-60) years. However, 109 (12.3\%) responses were received from consumers who had more than 60 years of age. The collected data comprises 385 $(43.3 \%)$ respondents with a high school diploma, and $283(31.8 \%)$ respondents had a bachelor's degree. However, $142(16.0 \%)$ respondents had a Master's degree, and $79(8.9 \%)$ respondents had academic or professional doctorate qualifications. Concerning the experience, 238 (26.8\%) respondents had (1-5) years of working exposure, 268 (30.1\%) had (5-10) years of working experience, $124(13.9 \%)$ responses were collected from the respondents that had (10-15) years of experiences, $119(13.4 \%)$ respondents had (15-20) years of work exposure, and $140(15.7 \%)$ responses were collected from the respondents that had more than 20 years of working experience. Lastly, as far as the income was concerned, it was recorded in US dollars, there were 394(44.3\%) respondents with $(2 \mathrm{~K}-4 \mathrm{~K})$ earning, $181(20.4 \%)$ respondents with $(4 \mathrm{~K}-6 \mathrm{~K})$ income. However, 154(17.3\%) respondents with $(6 \mathrm{~K}-8 \mathrm{~K})$ earning, 97 (10.9\%) respondents with (8K-10K) bracket of income, and $63(7.1 \%)$ respondents had higher than $10 \mathrm{~K}$ income in the US dollar per month, however, 'K' stands for thousands ' 000 '. 


\section{RESULTS AND DISCUSSION}

\subsection{Descriptive Statistics}

This research also used descriptive statistics to examine the essential characteristics of constructs, for this purpose, the data were converted into z-scores, and execute the descriptive statistics, the findings of Table 1 demonstrated that all the constructs remained between \pm 1.5 in terms of standard deviation and skewness, which exhibited that the collected data has a normality pattern. Moreover, the values of Kurtosis for all the constructs range from \pm 3 , which further substantiated that; the collected data exhibited the normality pattern, which is the pre-requisite for SEM-based multivariate techniques (Hair et al., 2010).

Tab. 1 - Descriptive statistics. Source: own research

\begin{tabular}{|l|l|l|l|l|l|l|l|}
\hline Factors & $\mathrm{N}$ & Mean & SD & \multicolumn{2}{l|}{ Skewness } & \multicolumn{2}{l|}{ Kurtosis } \\
\hline & Statistic & Statistic & Statistic & Statistic & SE & Statistic & SE \\
\hline $\begin{array}{l}\text { Impulse Buying } \\
\text { Behavior }\end{array}$ & 889 & 3.79 & 1.083 & -.894 & .082 & .270 & .164 \\
\hline $\begin{array}{l}\text { Fear of Complete } \\
\text { Lockdown }\end{array}$ & 889 & 3.76 & 1.079 & -.817 & .082 & .179 & .164 \\
\hline Peers Buying & 889 & 3.93 & 1.110 & -.953 & .082 & .310 & .164 \\
\hline $\begin{array}{l}\text { Scarcity of Essential } \\
\text { Products in Shelves }\end{array}$ & 889 & 3.89 & 1.013 & -.986 & .082 & 1.013 & .164 \\
\hline $\begin{array}{l}\text { Limited Supply of Es- } \\
\text { sential Goods }\end{array}$ & 889 & 3.95 & 1.123 & -.967 & .082 & .267 & .164 \\
\hline Panic Buying & 889 & 3.84 & 1.061 & -.935 & .082 & .528 & .164 \\
\hline US Stimulus Checks & 889 & 3.50 & 1.041 & -.557 & .082 & -.351 & .164 \\
\hline Fear Appeal & 889 & 3.92 & 1.105 & -.949 & .082 & .327 & .164 \\
\hline $\begin{array}{l}\text { Social Media Fake } \\
\text { News }\end{array}$ & 889 & 3.90 & 1.094 & -.941 & .082 & .371 & .164 \\
\hline COVID-19 & 889 & 3.89 & 1.092 & -.940 & .082 & .381 & .164 \\
\hline
\end{tabular}

\subsection{Reliabilities and Validities Analyses}

The rotated component matrix provided the factor loadings of all the items and constructs. We have calculated the composite reliabilities and average variance extracted with the help of factor loadings. The findings of Table 2 demonstrated that Cronbach's alpha and composite reliabilities are more significant than 0.90 , which meets the minimum threshold value of 0.60 (Huang et al., 2004). The findings of Table 2 further exhibited that the values of factor loadings of all the items are between 0.85-0.95 that justified the criterion of discriminant validities (Hair et al., 2010; Ahmed et al., 2019). Finally, the average variance extracted (AVE) values are higher than 0.50 for all the constructs. Thus, the criterion of convergent validities is also justified (Fornell \& Larcker, 1981). Both requirements of convergent and discriminant validities are pre-requisite to use SEMbased modeling techniques (Ahmed et al., 2020). 
Tab. 2 - Validities and Reliabilities. Source: own research

\begin{tabular}{|c|c|c|c|c|c|}
\hline Factors & Items & FL & CA & CR & AVE \\
\hline \multirow{3}{*}{ Impulse Buying Behavior } & IBB1 & .935 & .918 & .941 & .843 \\
\hline & IBB2 & .882 & & & \\
\hline & IBB3 & .937 & & & \\
\hline \multirow{3}{*}{ Fear of Complete Lockdown } & PB1 & .930 & .927 & .948 & .860 \\
\hline & PB2 & .905 & & & \\
\hline & PB3 & .947 & & & \\
\hline \multirow[t]{3}{*}{ Peers Buying } & PB1 & .930 & .928 & .949 & .861 \\
\hline & PB2 & .906 & & & \\
\hline & PB3 & .947 & & & \\
\hline \multirow[t]{3}{*}{ Scarcity of Essential Products in Shelves } & SES1 & .930 & .926 & .947 & .858 \\
\hline & SES2 & .904 & & & \\
\hline & SES3 & .945 & & & \\
\hline \multirow[t]{3}{*}{ Limited Supply of Essential Goods } & LSE1 & .925 & .921 & .943 & .848 \\
\hline & LSE2 & .906 & & & \\
\hline & LSE3 & .932 & & & \\
\hline \multirow[t]{3}{*}{ Panic Buying } & PNB1 & .933 & .928 & .949 & .860 \\
\hline & PNB2 & .904 & & & \\
\hline & PNB3 & .946 & & & \\
\hline \multirow[t]{3}{*}{ US Stimulus Checks } & USC1 & .930 & .926 & .947 & .858 \\
\hline & USC2 & .902 & & & \\
\hline & USC3 & .947 & & & \\
\hline \multirow[t]{3}{*}{ Fear Appeal } & FA1 & .932 & .925 & .946 & .855 \\
\hline & FA2 & .904 & & & \\
\hline & FA3 & .938 & & & \\
\hline \multirow[t]{3}{*}{ Social Media Fake News } & SMFN1 & .930 & .922 & .944 & .850 \\
\hline & SMFN2 & .905 & & & \\
\hline & SMFN3 & .932 & & & \\
\hline \multirow[t]{3}{*}{ COVID-19 } & COV1 & .929 & .919 & .942 & .845 \\
\hline & COV2 & .902 & & & \\
\hline & COV3 & .927 & & & \\
\hline
\end{tabular}

Note: IBB: Impulse buying behavior; FCL, Fear of complete lockdown, PB: Peers buying, SES: Scarcity of essential products in shelves, LSE: Limited supply of essential goods, PNB: Panic buying, USC: US stimulus checks, FA: Fear appeal, SMFNL Social media fake news

\subsection{Exploratory Factor Analysis - EFA}

In SEM-based modeling, the exploratory factor analysis (EFA) is the most vital component in evaluating and validating the items and constructs. The EFA method also reduces unnecessary 
items and constructs. Thus, the EFA has a proficiency to condense a large amount of data, according to Emory \& Cooper (1991); the EFA helps the researcher validate and retain constructs and items. The findings of the principal component rotated matrix substantiate the construct validities of items and constructs. In our hypothesized measurement model, the impulse buying behavior, Fear of Complete Lockdown, Peers Buying, Scarcity of Essential Products in Shelves, Limited Supply of Essential Goods, Panic Buying, and US Stimulus Checks, Fear Appeal, Social media fake news, and COVID-19 have comprised of three items each. The findings exhibited that the values of factor loadings for each item and variable are higher than 0.60 , which validated the retention of items and constructs (Ahmed et al., 2020; Kaiser, 1974).

\subsection{Kaiser Meyer Olkin (KMO) and Bartlett's Analyses}

The findings of Kaiser Meyer Olkin (KMO) analysis suggested that the value of KMO is 0.712 , which is good as demonstrated by Kaiser (1974); the values ranging between $0.70-0.79$ are considered to be good. However, the values ranging from $0.80-0.99$ are considered to be being excellent. Finally, the outcomes of Bartlett's Sphericity technique showed $\mathrm{p}<0.05$, which confirmed that the correlation between items and constructs is significant and satisfactory at the $5 \%$ level of significance (Kaiser, 1974).

\subsection{Total Variance Explained}

The findings of the cumulative variance percentage of the ten factors considered show a dispersion of variance of potential factors. The aggregate variance percentage value is $85.99 \%$, which is deemed to be excellent because the minimum threshold value is $50 \%$. The findings further demonstrated that the total of each factor's Eigenvalue is higher than 1. Hence, both cumulative variance dispersion and Eigenvalues established that our collected data is reliable, and now, we can employ further analyses.

\subsection{Confirmatory Factor Analysis - CFA}

The confirmatory factor analysis (CFA) is a direct and appropriate approach to scrutinize the measurement model. The CFA technique further established the fitness of data for the hypothesized measurement model (Hair et al., 2010; Ahmed et al., 2019). The hypothesized measurement model for this study considered the antecedents of impulse buying behavior such as FCL, PB, SES, LSE, PNB, and USC. Fear appeal and social media fake news are considered to be mediating variables. However, COVID-19 is taken as moderator, and impulse buying behavior as an outcome variable. In our hypothesized measurement model, we have taken thirty items of ten factors, and fix the sample data between unobserved and observed variables (Ahmed et al., 2020; Fornell \& Larcker, 1981). The findings of Table 3 showed that the factor loadings between factors and items range from $0.85-0.95$, which established that the overall measurement model is acceptable. The findings further substantiated the hypothesized measurement model's convergent validities through average variance extracted (AVE) in which all the factors have higher than 0.50 AVE values (Fornell \& Larcker, 1981). 


\subsection{Structural Equation Modeling - SEM}

For the estimation of parameters of impulse buying behavior, we used structural equation modeling. Our structural model had six independent variables: FCL, PB, SES, LSE, PNB, and USC. Moreover, Fear appeal and social media fake news were considered as mediating variables. However, COVID-19 has been considered as a moderating variable, and impulse buying behavior as an outcome variable. The findings demonstrated that our hypothesized structural model is adequate in light of the threshold of fit-indices measures. The findings of Table 3 exhibited the fit-indices measures for the structural model are within the range of threshold limits. Thus, it is finally established that our constructed structural model is a suitable instrument.

Tab. 3 - Fit Indices Measures. Source: own research

\begin{tabular}{|c|c|c|c|c|c|c|c|c|c|c|c|}
\hline \multirow{2}{*}{$\begin{array}{l}\text { Good- } \\
\text { ness of Fit } \\
\text { Measures }\end{array}$} & \multicolumn{3}{|c|}{ Absolute Fit Indices } & \multicolumn{3}{|c|}{ Relative Fit Indices } & \multicolumn{3}{|c|}{$\begin{array}{l}\text { Non-centrality- } \\
\text { based Indices }\end{array}$} & \multicolumn{2}{|c|}{$\begin{array}{l}\text { Parsimonious } \\
\text { Fit Indices }\end{array}$} \\
\hline & $\begin{array}{l}\chi^{2} / \\
\mathrm{df}\end{array}$ & $\begin{array}{l}\text { Prob- } \\
\text { ability }\end{array}$ & GFI & NFI & IFI & TLI & CFI & $\begin{array}{l}\text { RM- } \\
\text { SEA }\end{array}$ & RNI & PCFI & PNFI \\
\hline $\begin{array}{l}\text { Measure- } \\
\text { ment } \\
\text { Model }\end{array}$ & 3.41 & .0154 & .97 & .93 & .96 & .96 & .97 & .019 & .97 & .82 & .84 \\
\hline $\begin{array}{l}\text { Structural } \\
\text { Model }\end{array}$ & 3.42 & .0169 & .99 & .95 & .98 & .97 & .99 & .017 & .98 & .83 & .85 \\
\hline $\begin{array}{l}\text { Criterion } \\
\text { (Thresh- } \\
\text { old values) }\end{array}$ & $\begin{array}{l}< \\
5.0\end{array}$ & $<.05$ & $>.95$ & $>.90$ & $>.95$ & $>.95$ & $>.95$ & $<.05$ & $>.95$ & $>.75$ & $>.75$ \\
\hline
\end{tabular}

Note. TLI=Tucker-Lewis Index; $\chi^{2} / \mathrm{d}=$ Relative Chi-square; GFI=Goodness of Fit Index; RMSEA=Root mean squared error of approximation; $\mathrm{CFI}=\mathrm{Comparative}$ fit index; NFI=Normed fixed index; IFI=Incremental fixed index; RNI= Relative Non-centrality Index; PNFI=Parsimony-adjusted normed fit index; PCFI=Parsimonious-adjusted fit index.

\subsection{Hypothesized Direct Relationship}

For the evaluation of the hypothesized direct relationship, we used standardized regression weights to infer the association between independent variables such as FCL, PB, SES, LSE, \&USC, and impulse buying behavior from the perspective of US consumers. The findings of Table 4 exhibit that our framed direct hypotheses (H1-H6) are sustained, as $\mathrm{T}>2$ and $\mathrm{p}<0.05$ in all six hypotheses. Therefore, it is concluded that FCL, PB, SES, LSE, PNB, and USC have had a positive and significant impact on the impulse buying behavior of US citizens. However, the individual outcomes indicate that the PNB and FCL had the most potent influences, 0.8439 and 0.8225 correspondingly. Nevertheless, LSE has an impact of 0.7254 , followed by the SES with 0.3332 , and USC has an effect of 0.1198 on impulse buying behavior. These results are consistent with the previous literature (Kim, 2020; Arnold \& Reynolds, 2012; Ansari et al., 2008; Kim \& Forsythe, 2010). 
Tab. 4 - Hypothesized Direct Relationship. Source: own research

\begin{tabular}{|c|c|c|c|c|c|c|c|}
\hline $\begin{array}{l}\text { Hy- } \\
\text { poth- } \\
\text { eses }\end{array}$ & Variables & $\begin{array}{l}\text { Regres- } \\
\text { sion } \\
\text { Paths }\end{array}$ & $\begin{array}{l}\text { Stand- } \\
\text { ardized } \\
\text { Regression } \\
\text { weights }(\beta)\end{array}$ & SE & $\mathrm{T}$ & $\mathrm{P}^{*}$ & Decision \\
\hline $\mathrm{H} 1$ & $\begin{array}{l}\text { Fear of Com- } \\
\text { plete Lock- } \\
\text { down }\end{array}$ & $\begin{array}{l}\mathrm{FCL}+\rightarrow \\
\mathrm{IBB}\end{array}$ & .8225 & .099 & 41.319 & .0000 & $\begin{array}{l}\text { Sup- } \\
\text { ported }\end{array}$ \\
\hline $\mathrm{H} 2$ & Peers Buying & $\begin{array}{l}\mathrm{PB} \dagger \\
\rightarrow \mathrm{IBB}\end{array}$ & .2084 & .023 & 8.775 & .0000 & $\begin{array}{l}\text { Sup- } \\
\text { ported }\end{array}$ \\
\hline H3 & $\begin{array}{l}\text { Scarcity of Es- } \\
\text { sential Products } \\
\text { in Shelves }\end{array}$ & $\begin{array}{l}\mathrm{SES}+\rightarrow \\
\mathrm{IBB}\end{array}$ & .3332 & .035 & 9.489 & .0000 & $\begin{array}{l}\text { Sup- } \\
\text { ported }\end{array}$ \\
\hline $\mathrm{H} 4$ & $\begin{array}{l}\text { Limited Supply } \\
\text { of Essential } \\
\text { Goods }\end{array}$ & $\begin{array}{l}\mathrm{LSE}+\rightarrow \\
\mathrm{IBB}\end{array}$ & .7254 & .018 & 25.841 & .0000 & $\begin{array}{l}\text { Sup- } \\
\text { ported }\end{array}$ \\
\hline H5 & Panic Buying & $\begin{array}{l}\mathrm{PNB}+ \\
\rightarrow \mathrm{IBB}\end{array}$ & .8439 & .019 & 42.431 & .0000 & $\begin{array}{l}\text { Sup- } \\
\text { ported }\end{array}$ \\
\hline H6 & $\begin{array}{l}\text { US Stimulus } \\
\text { Checks }\end{array}$ & $\begin{array}{l}\mathrm{USC}+\rightarrow \\
\mathrm{IBB}\end{array}$ & .1198 & .035 & 3.383 & .0007 & $\begin{array}{l}\text { Sup- } \\
\text { ported }\end{array}$ \\
\hline
\end{tabular}

Note: $\dagger=$ Predictor; ${ }^{*} \mathrm{p}<0.05$ (rejected at $5 \%$ level of significance)

\subsection{Mediation Analysis}

The findings of Table 5 exhibit the mediating influence of Fear Appeal and social media fake news in the relationship of exogenous variables, such as FCL, PB, SES, LSE, PNB, and USC, as well as endogenous variables in the case of US consumers during the COVID-19 pandemic across the United States. The outcomes of mediation have been measured through bootstrapping and the Normal theory methods. The research undertaken has framed and examined two sets of six hypotheses, for instance, H7A to H7F and H8A to H8F. According to Hayes \& Rockwood (2020), and Ahmed et al. (2020), we examined using a bootstrapping approach zero between BootLLCI and BootULCI, since zero does not occur between the $95 \%$ bias-corrected bootstrapping confidence interval. Thus, we concluded that there is a perfect mediation. Consequently, the findings of Table 5 establish that the mediating variables such as Fear Appeal and social media fake news have had a potent mediation between exogenous factors and the impulse buying behavior of US citizens. The Normal theory method has demonstrated similar outcomes because of $Z> \pm 1.96$ and $p<0.05$ in all the cases. Therefore, it is established that both sets of six hypotheses, for instance, H7A to $\mathrm{H} 7 \mathrm{~F}$ and $\mathrm{H} 8 \mathrm{~A}$ to $\mathrm{H} 8 \mathrm{~F}$, are supported. The previous literature has also demonstrated that Fear Appeal and social media fake news have a significant influence on impulse buying behavior as a mediating variable (Iyer et al., 2020; Kim \& Su, 2020; Przybylski et al., 2013; Riordan et al., 2018; Wegmann et al., 2017; Lai et al., 2016; Carson, 2017; Ferencakova et al., 2020). 
Tab. 5 - Mediation Analysis. Source: own research

\begin{tabular}{|c|c|c|c|c|c|c|c|c|c|}
\hline \multirow{2}{*}{$\begin{array}{l}\text { Hy- } \\
\text { poth- } \\
\text { eses }\end{array}$} & \multirow[t]{2}{*}{ Mediation } & \multicolumn{4}{|c|}{ Bootstrapping Method } & \multicolumn{4}{|c|}{ Normal Theory Method } \\
\hline & & $\begin{array}{l}\text { Indi- } \\
\text { rect } \\
\text { Effect }\end{array}$ & $\begin{array}{l}\text { Boot } \\
\text { SE }\end{array}$ & $\begin{array}{l}\text { Boot } \\
\text { LLCI }\end{array}$ & $\begin{array}{l}\text { Boot } \\
\text { ULCI }\end{array}$ & $\begin{array}{l}\text { Indi- } \\
\text { rect } \\
\text { Effect }\end{array}$ & SE. & $\mathrm{Z}^{*}$ & Prob.** \\
\hline H7A: & $\mathrm{FCL} \rightarrow \mathrm{FA} \rightarrow \mathrm{IBB}$ & .353 & .023 & .730 & .821 & .353 & .020 & 17.60 & .0000 \\
\hline H7B: & $\mathrm{PB} \rightarrow \mathrm{FA} \rightarrow \mathrm{IBB}$ & .311 & .024 & .264 & .359 & .311 & .019 & 15.85 & .0000 \\
\hline H7C: & $\mathrm{SES} \rightarrow \mathrm{FA} \rightarrow \mathrm{IBB}$ & .442 & .024 & .393 & .491 & .442 & .023 & 18.85 & .0000 \\
\hline H7D: & $\mathrm{LSE} \rightarrow \mathrm{FA} \rightarrow \mathrm{IBB}$ & .358 & .023 & .313 & .403 & .358 & .020 & 17.92 & .0000 \\
\hline H7E: & $\mathrm{PNB} \rightarrow \mathrm{FA} \rightarrow \mathrm{IBB}$ & .356 & .022 & .313 & .402 & .356 & .023 & 15.27 & .0000 \\
\hline H7F: & $\mathrm{USC} \rightarrow \mathrm{FA} \rightarrow \mathrm{IBB}$ & .052 & .018 & .017 & .089. & .052 & .015 & 3.33 & .0000 \\
\hline H8A: & $\mathrm{FCL} \rightarrow \mathrm{SMFN} \rightarrow \mathrm{IBB}$ & .421 & .024 & .372 & .469 & .421 & .021 & 19.98 & .0000 \\
\hline H8B: & $\mathrm{PB} \rightarrow \mathrm{SMFN} \rightarrow \mathrm{IBB}$ & .358 & .024 & .310 & .407 & .358 & .021 & 16.33 & .0000 \\
\hline H8C: & $\mathrm{SES} \rightarrow \mathrm{SMFN} \rightarrow \mathrm{IBB}$ & .490 & .024 & .443 & .538 & .490 & .022 & 21.74 & .0000 \\
\hline H8D: & $\mathrm{LSE} \rightarrow \mathrm{SMFN} \rightarrow \mathrm{IBB}$ & .429 & .022 & .386 & .474 & .429 & .021 & 20.12 & .0000 \\
\hline H8E: & $\mathrm{PNB} \rightarrow \mathrm{SMFN} \rightarrow \mathrm{IBB}$ & .428 & .024 & .381 & .479 & .428 & .020 & 20.70 & .0000 \\
\hline H8F: & $\mathrm{USC} \rightarrow \mathrm{SMFN} \rightarrow \mathrm{IBB}$ & .069 & .021 & .029 & .112 & .069 & .018 & 3.73 & .0002 \\
\hline
\end{tabular}

$*$ denotes the values of $Z>1.96$ and $Z>-1.96$; ** denotes $\mathrm{p}<0.05$. Decision : supported.

\subsection{Moderation Analysis}

The findings of Table 6 demonstrate the moderation of the COVID-19 pandemic in an association of exogenous, for instance, Fear of Complete Lockdown, Peers Buying, Scarcity of Essential Products on Shelves, Limited Supply of Essential Goods, Panic Buying, and US Stimulus Checks, and impulse buying behavior as an outcome variable during the COVID-19 pandemic. Thus, the results demonstrate that the hypotheses $\mathrm{H} 9 \mathrm{~A}$ through $\mathrm{H} 9 \mathrm{~F}$ are supported, as $\mathrm{T}>2$ and $\mathrm{p}<0.05$ in all the hypotheses from H9A to H9F (Hayes \& Rockwood, 2020). It is thus finally established that COVID-19 has played a substantial moderating role amid exogenous (FCL, PB, SES, LSE, PNB \& USC) and endogenous variables, i.e., the impulse buying behavior of the US citizens during novel Coronavirus pandemic phenomenon across the United States. Previous studies such as Iyer et al. (2020), Pekerşen \& Tugay (2020), and Addo et al. (2020) have also demonstrated similar results.

Tab. 6 - Moderating Effect. Source: own research

\begin{tabular}{|l|l|l|l|l|l|l|l|l|}
\hline Hypotheses & $\begin{array}{l}\text { Mod- } \\
\text { erator }\end{array}$ & $\begin{array}{l}\text { Mod- } \\
\text { eration }\end{array}$ & $\begin{array}{l}\text { Coef- } \\
\text { ficient }\end{array}$ & SE & T & P* & LLCI & ULCI \\
\hline Moderating Effect of COVID-19 b/w FCL and IBB \\
\hline H9A: & $\begin{array}{l}\text { COV- } \\
\text { ID-19 }\end{array}$ & $\begin{array}{l}\text { FCL } \mathrm{x} \\
\text { COV }\end{array}$ & -.2206 & .0135 & -16.2868 & .0000 & -.2472 & -.1941 \\
\hline
\end{tabular}




\begin{tabular}{|c|c|c|c|c|c|c|c|c|}
\hline H11B: & $\begin{array}{l}\text { COV- } \\
\text { ID-19 }\end{array}$ & $\begin{array}{l}\mathrm{PB} x \\
\mathrm{COV}\end{array}$ & -.0708 & .0124 & -5.7259 & .0000 & -.0951 & -.0465 \\
\hline \multicolumn{9}{|c|}{ Moderating Effect of COVID-19 b/w SES and IBB } \\
\hline H12A: & $\begin{array}{l}\text { COV- } \\
\text { ID-19 }\end{array}$ & $\begin{array}{l}\text { SES } x \\
\text { COV }\end{array}$ & -.1536 & .0146 & -10.5416 & .0000 & -.1822 & -.1250 \\
\hline \multicolumn{9}{|c|}{ Moderating Effect of COVID-19 b/w LSE and IBB } \\
\hline H12B: & $\begin{array}{l}\text { COV- } \\
\text { ID-19 }\end{array}$ & $\begin{array}{l}\text { LSE x } \\
\text { COV }\end{array}$ & -.1710 & .0135 & -12.6803 & .0000 & -.1974 & -.1445 \\
\hline \multicolumn{9}{|c|}{ Moderating Effect of COVID-19 b/w PNB and IBB } \\
\hline H12A: & $\begin{array}{l}\text { COV- } \\
\text { ID-19 }\end{array}$ & $\begin{array}{l}\text { PNB x } \\
\text { COV }\end{array}$ & -.1533 & .0137 & -11.1834 & .0000 & -.1802 & -.1264 \\
\hline \multicolumn{9}{|c|}{ Moderating Effect of COVID-19 b/w USC and IBB } \\
\hline H12B: & $\begin{array}{l}\text { COV- } \\
\text { ID-19 }\end{array}$ & $\begin{array}{l}\text { USC } \mathrm{x} \\
\mathrm{COV}\end{array}$ & -.0530 & .0177 & -2.9987 & .0028 & -.0877 & -.0183 \\
\hline
\end{tabular}

Note: Moderator $=$ COV $=$ COVID-19; $*$ Signifies rejection of Hypotheses at $95 \%$ confidence interval $(\mathrm{p}<0.05)$; ' $\mathrm{x}$ ' is known as the multiplicative sign.

\subsection{Virtualization of Conditional Effect}

According to Hayes \& Rockwood (2020), and Ahmed et al. (2020), a graphical depiction is a basic form to establish the moderation, as it clearly shows the moderating variable between exogenous and endogenous variables. The results of Figure $2 \mathrm{a}$ to Figure $2 \mathrm{f}$ depict that the effect of the impulse buying behavior changes with the perpetual change of moderating variables such as the COVID-19 pandemic; however, the exogenous variables remained constant. Hence, it is confirmed that COVID-19 has had a significant impact between exogenous variables such as FCL, PB, SES, LSE, PNB, and USC, and impulse buying behavior of US citizens. In Figures 2a to 2f, light gray exhibits the exogenous factors, dark gray indicates the moderator COVID-19, and the black color shows the influence of impulse buying behavior.
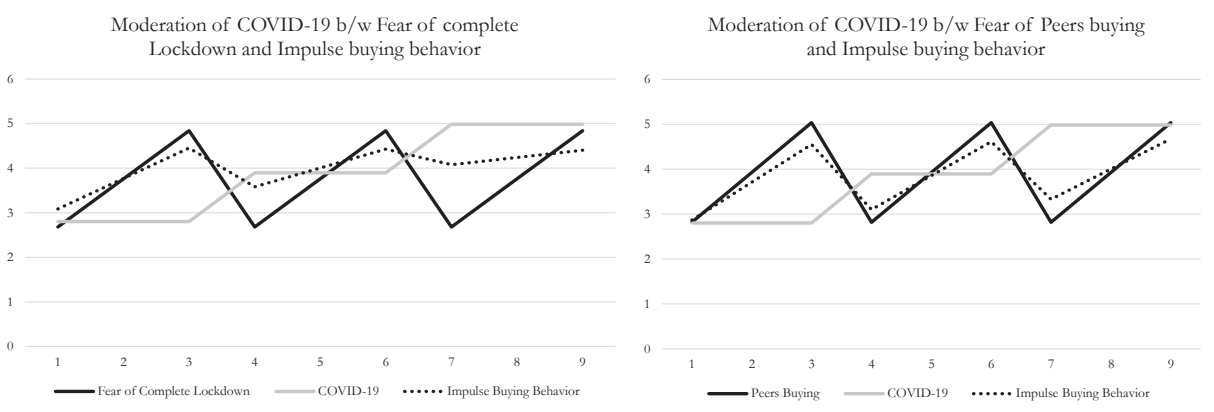

Fig. $2 a$

Fig. $2 b$ 


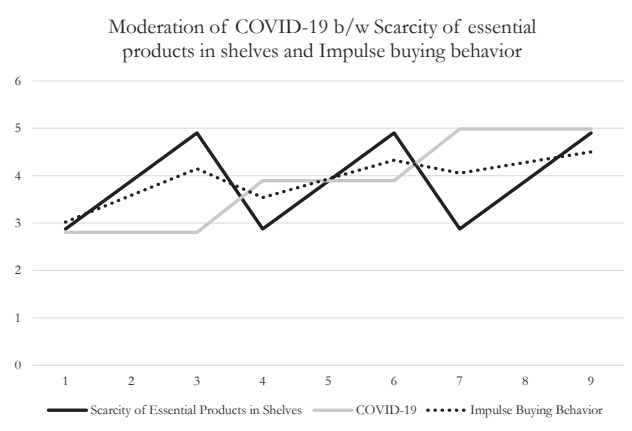

Fig. $2 c$

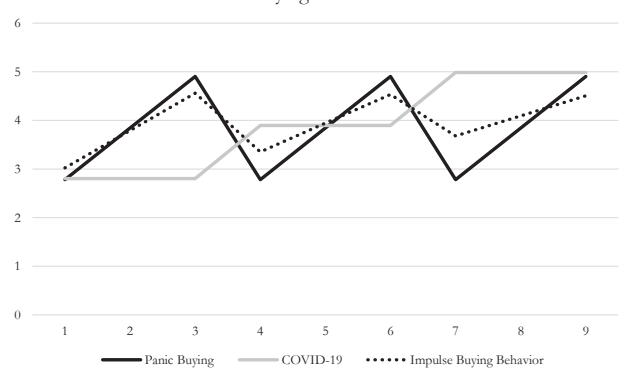

Fig. $2 e$

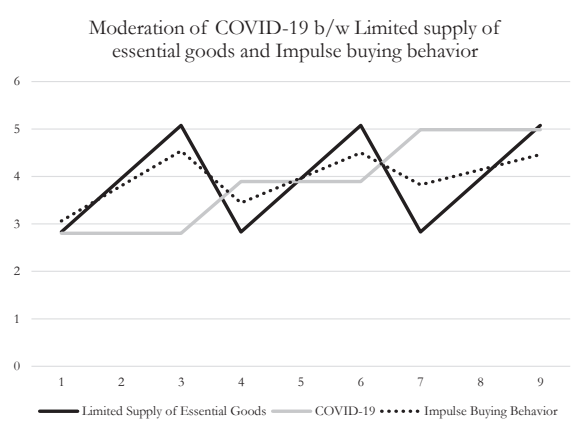

Fig. $2 d$

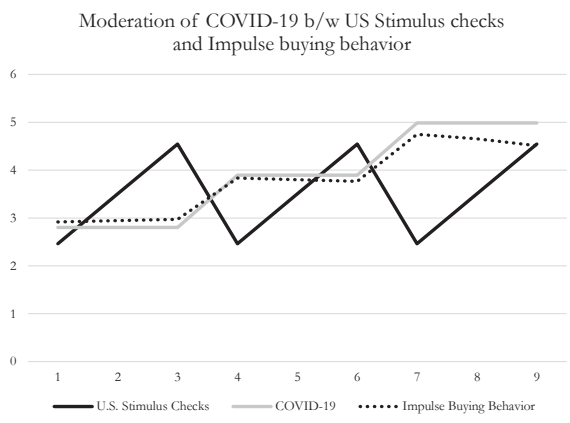

Fig. $2 f$

Fig. 2 (a-f) -The visualizing conditional effect of a moderator (COVID-19) b/w Exogenous variables (FCL, SES, LSE, PNB \& USC) and endogenous variable such as Impulse buying behavior. Source: own research

\section{CONCLUSION}

The undertaken study examines the antecedents of impulse buying behavior and its influence on US citizens' buying patterns. The findings demonstrate that fear of a complete lockdown and panic buying are the essential influencers on the US population's purchase behavior. Other factors such as peers buying, scarcity of essential items on superstore shelves, disruption of the supply chain, and the US stimulus package also play a vital role in the impulse buying behavior of US citizens. We used the two mediating factors of Fear Appeal and social media fake news, and evaluated the mediation between exogenous and impulse purchase patterns. Our findings confirm that misuse and uncontrolled spread of fake news transmitted through social media further aggravated the situation, and people indulge in abnormal purchase patterns. Similarly, Fear Appeal also has a vital influence as a mediating factor on impulse buying behavior. Finally, we employed COVID-19 as a moderator in the undertaken study and the analysis of the moderation between the exogenous and outcome variable. Using an evaluation of the US population, our findings demonstrate that COVID-19 is a factor that influenced life and thought patterns. 
COVID-19 is the strongest variable affecting consumer purchasing behavior. The US citizens tilted towards impulse buying behavior analyzed essential and non-essential goods across the United States. The findings of the undertaken research should suggest practical implications, mainly for government agencies, policymakers, marketers, and other practitioners in terms of how to create and institute distinct strategies to deal with unpredictable situations during the COVID-19 phenomenon. Marketers and brand managers can devise novel strategies to enhance their brand's market share to attain a competitive advantage in COVID-19 or similar panic situations in the future.

The constructs that are used in this research are not comprehensive and conclusive to a sufficient degree; future studies can incorporate new dimensions for more generalized and robust outcomes. The outbreak of the COVID-19 pandemic was abrupt. The collected data has limitations; for instance, the duration and timing of the undertaken study. Future research studies can further substantiate and establish the study's findings. Another limitation of this study is the specificity of the data collection, since the data was collected from US citizens that were severely hit by the coronavirus measures. Thus, the results cannot be generalized to other populations of the world. Therefore, it is suggested that future researchers carry out similar studies on a larger scale, including other countries, to confirm the dimensions of impulse buying behavior.

Questionnaire Link: https://www.researchgate.net/publication/343683153_Questionnaire_-_ COVID-19_Pandemic_and_Antecedents_of_Impulse_Buying_Behavior_in_the_US_Citizens

\section{References}

1. Abel, J. P., Buff, C. L., \& Burr, S. A. (2016). Social media and the Fear of missing out: Scale development and assessment. Journal of Business \& Economics Research, 14 (1), 33-44. https://doi. org/10.19030/jber.v14i1.9554

2. Adam, A. I. (2020). Impact of Visual Merchandising on Customer Impulse buying behavior in retail stores in Sudan. Asian Journal of Management, 11 (1), 29. https://doi.org/10.5958/23215763.2020 .00006 .2

3. Addo, P. C., Jiaming, F., Kulbo, N. B., \& Liangqiang, L. (2020). COVID-19: Fear appeal favoring purchase behavior towards personal protective equipment. The Service Industries Journal, 40 (7-8), 471-490. https://doi.org/10.1080/02642069.2020.1751823

4. Ahmed, R. R., Hussain, S., Pahi, M. H., Usas, A., \& Jasinskas, E. (2019). Social Media Handling and Extended Technology Acceptance Model (ETAM): Evidence from SEM-based Multivariate Approach. Transformations in Business \& Economics, 3 (48), 246-271.

5. Ahmed, R. R., Salman, F., Malik, S. A., Štreimikiené, D., Soomro, R. H., \& Pahi, M. H. (2020). Smartphone use and Academic performance of University Students: A Mediation and Moderation Analysis. Sustainability, 12 (1), 439. https://doi.org/10.3390/su12010439

6. Allon, G., \& Bassamboo, A. (2011). Buying from the babbling retailer? The impact of availability information on customer behavior. Management Science, 57 (4), 713-726. https://doi. $\operatorname{org} / 10.1287 / \mathrm{mnsc} .1100 .1306$

7. Ansari, A., Mela, C. F., \& Neslin, S. A. (2008). Customer Channel Migration. Journal of Marketing Research, 45 (1), 60-76. https://doi.org/10.1509/jmkr.45.1.60 
8. Arnold, M. J., \& Reynolds, K. E. (2012). Approach and Avoidance motivation: Investigating hedonic consumption in a retail Setting. Journal of Retailing, 88 (3), 399-411. https://doi. org/10.1016/j.jretai.2011.12.004

9. Bergel, M., \& Brock, C. (2019). Visitors' loyalty and price perceptions: The role of customer engagement. Service Industries Journal, 39 (7-8), 575-589. https://doi.org/10.1080/02642069.201 9.1579798

10. Boutsouki, C. (2019). Impulse behavior in economic crisis: A data driven market segmentation. International Journal of Retail \& Distribution Management, 47 (9), 974-996. https:// doi.org/10.1108/ijrdm-08-2018-0165

11. Byrne, B. M. (2009). Structural Equation Modeling with AMOS, Basic Concepts, Application and Programming. 2nd ed. Trenton, NJ: La Erlbaum Associates.

12. Carson, N. (2017). When you're not invited to the party: Fear of missing out and authenticity for youth online. Journal of the American Academy of Child and Adolescent Psychiatry, 56 (10), 90-91. https://doi.org/10.1016/j.jaac.2017.07.356

13. Čepel, M. (2019). Social and Cultural Factors and Their Impact On The Quality Of Business Environment In the SME Segment. International Journal of Entrepreneurial Knowledge, 7 (1), 65-73. https://doi.org/10.2478/ijek-2019-0005

14. CNN (2020). People receiving stimulus checks get a letter signed by President Donald Trump. CNN News. Retrieved April 29, 2020, from https://www.cnn.com/2020/04/26/politics/ stimulus-check-coronavirus-letter-donald-trump/index.html

15. Crabble, M. (2020). Research Your Way Out of a Crisis: Covid-19's Effect on Consumer Behaviour. Mintel Blog. Retrieved March 28, 2020, from https://www.mintel.com/blog/ consumer-market-news/research-your-way-out-of-a-crisis-covid-19s-effect-on-consumerbehaviour

16. De Veirman, M., Cauberghe, V., \& Hudders, L. (2017). Marketing through Instagram influencers: The impact of number of followers and product divergence on brand attitude. International Journal of Advertising, 36 (5), 798-828. https://doi.org/10.1080/02650487.2017.134 8035

17. Dobrovič, J., Kmeco, L., Gallo, P., \& Gallo jr., P. (2019). Implications of the Model EFQM as a Strategic Management Tool in Practice: A Case of Slovak Tourism Sector. Journal of Tourism and Services, 10 (18), 47-62. https://doi.org/10.29036/jots.v10i18.91

18. Dvorský, J., Petráková, Z., \& Polách, J. (2019). Assessing the Market, Financial, and Economic Risk Sources by Czech and Slovak SMEs. International Journal of Entrepreneurial Knowledge, 7 (2), 30-40. https://doi.org/10.12345-0008

19. Emory, C. W., \& Cooper, D. R. (1991). Business Research Methods. 4th ed. Boston: Irwin.

20. Ferencakova, L., Gajdka, K., Netek, V., \& Kapoun, P. (2020). Engaging Customers on Facebook Coffee Shops' Brand-Fan Pages. International Journal of Entrepreneurial Knowledge, 8 (1), 65-75. https://doi.org/10.37335/ijek.v8i1.110

21. Fornell, C., \& Larcker, D. F. (1981). Evaluating structural equation models with unobservable variables and measurement error. Journal of Marketing Research, 18 (1), 39-50. https://doi. org/10.1177/002224378101800104 
22. Foroughi, A., Buang, N. A., CheSenik, Z., Sadat \& Hajmisadeghi, R. (2013). Impulse buying Behaviour and Moderating role of gender among Iranian Shoppers. Journal of Basic and Applied Scientific Research, 3 (4), 760-769.

23. Garrett, L. (2020). COVID-19: the medium is the message. Lancet, 395, 942-943. https://doi. org/10.1016/s0140-6736(20)30600-0

24. Guitton, M. J. (2020). Cyberpsychology research and COVID-19. Computers in Human Behavior, 111, 106357. https://doi.org/10.1016/j.chb.2020.106357

25. Güler, Y. B. (2014). Values and hedonic consumption behavior: A field research in Kirikkale. Asian Journal of Empirical Research, 23 (3-4), 167-180.https://doi.org/10.1080/08961530.2011.5 78056

26. Hair, J. F., Black, W. C., Babin, B. J., \&Anderson, R. E. (2010). Multivariate Data Analysis. 7th ed. New Jersey: Prentice Hall: Upper Saddle River.

27. Haq, M., \& Abbasi, S. (2016). Indirect impact of hedonic consumption and emotions on impulse purchase behavior: A double mediation model. Journal of Management Sciences, 3 (2), 108-122. https://doi.org/10.20547/jms.2014.1603202

28. Hayes, A. F., \&Rockwood, N. J. (2020). Conditional process analysis: Concepts, computation, and advances in modeling of the contingencies of mechanisms. American Behavioral Scientist, 64 (1), 19-54. https://doi.org/10.1177/0002764219859633

29. Huang, J. H., Lee, B. C. Y., \& Ho, S. H. (2004). Consumer attitude toward grey market goods. International Marketing Review, 21 (6), 598-614. https://doi.org/10.1108/02651330410568033

30. INSEAD. (2020). The Psychology behind coronavirus panic buying. Retrieved March 29, 2020. https://knowledge.insead.edu/node/13451/pdf

31. Iyer, G. R., Blut, M., Xiao, S. H., \& Grewal, D. (2020). Impulse buying: a meta-analytic review. Journal of the Academy of Marketing Science, 48 (3), 384-404. https://doi.org/10.1007/s11747-01900670-w

32. Kaiser, H. F. (1974). An index of factorial simplicity. Psychometrika, 39 (1), 31-36. https://doi. org/10.1007/bf02291575

33. Khan, K. A., Çera, G., \& Nétek, V. (2019). Perception of the Selected Business Environment Aspects by Service Firms. Journal of Tourism and Services, 10 (19), 111-127. https://doi. org/10.29036/jots.v10i19.115

34. Kim, B. (2020). Effects of Social Grooming on Incivility in COVID-19. Cyberpsychology, Behavior, and Social Networking. https://doi.org/10.1089/cyber.2020.0201

35. Kim, J., \& Forsythe, S. (2010). Factors affecting adoption of product virtualization technology for online consumer electronics shopping. International Journal of Retail and Distribution Management, 38 (3), 190-204. https://doi.org/10.1108/09590551011027122

36. Kim, S. W., \& Su, K. P. (2020). Using psychoneuroimmunity against COVID-19. Brain, Behavior, and Immunity, 87, 4-5. https://doi.org/10.1016/j.bbi.2020.03.025

37. Koparal, C., \& Çalik, N. (2015). Hedonic consumption characteristics related to products and services where Fashion Involvement Plays an important role, A Field study from Eskisehir, Turkey. International Journal of Social Sciences, 4 (1), 14-39. https://doi.org/10.20472/ss2015.4.1.002 
38. Kossman, S. (2016). Survey: 5 in 6 Americans admit to impulse buys. Retrieved May 26, 2020. https://www.creditcards.com/credit-card-news/impulse-buy-survey.php

39. Lai, C., Altavilla, D., Ronconi, A., \& Aceto, P. (2016). Fear of missing out (FOMO) is associated with activation of the right middle temporal gyrus during inclusion social cue. Computers in Human Behavior, 61, 516-521. https://doi.org/10.1016/j.chb.2016.03.072

40. Leverin, A., \& Liljander, V. (2006). Does relationship marketing improve customer relationship satisfaction and loyalty? International Journal of Bank Marketing, 24 (4), 232-251. https://doi.org/10.1108/02652320610671333

41. Limaye, R. J., Sauer, M., Ali, J., Bernstein, J., Wahl, B., Barnhill, A., \& Labrique, A. (2020). Building trust while influencing online COVID-19 content in the social media world. Lancet Digital Health, 2 (6), 277-278. https://doi.org/10.1016/s2589-7500(20)30084-4

42. Liu, P., He, J., \& Li, A. (2019). Upward social comparison on social network sites and impulse buying: A moderated mediation model of negative affect and rumination. Computers in Human Behavior, 96, 133-140. https://doi.org/10.1016/j.chb.2019.02.003

43. Mogilner, C., Aaker, J., \& Kamvar, S. D. (2012). How Happiness affects Choice. Journal of Consumer Research, 39 (2), 429-443. https://doi.org/10.1086/663774

44. Numerator Intelligence (2020). The Impact of Coronavirus (COVID-19) on Consumer Behavior. Internet Blog, Retrieved April 20, 2020. https://www.numerator.com/resources/ blog/update-impact-coronavirus-consumer-behavior

45. Oberst, U., Wegmann, E., Stodt, B., Brand, M., \& Chamarro, A. (2017). Negative consequences from heavy social networking in adolescents: The mediating role of Fear of missing out. Journal of Adolescence, 55, 51-60. https://doi.org/10.1016/j.adolescence.2016.12.008

46. Parsad, C. (2020). Comparing between product-specific and general impulse buying tendency: Does shoppers' personality influence their impulse buying tendency? Asian Academy of Management Journal, 24 (2), 41-61. https://doi.org/10.21315/aamj2019.24.2.3

47. Pekerşen, Y., \& Tugay, O. (2020). Professional Satisfaction as a Key Factor in Employee Retention: A case of the Service Sector. Journal of Tourism and Services, 11 (20), 1-27. https://doi. org/10.29036/jots.v11i20.123

48. Przybylski, A. K., Murayama, K., De Haan, C. R., \& Gladwell, V. (2013). Motivational, emotional, and behavioral correlates of Fear of missing out. Computers in Human Behavior, 29 (4), 1841-1848. https://doi.org/10.1016/j.chb.2013.02.014

49. Rajan, K. A. (2020). Influence of hedonic and utilitarian motivation on impulse and rational buying behavior in online shopping. Journal of Statistics and Management Systems, 23 (2), 419-430. https://doi.org/10.1080/09720510.2020.1736326

50. Riordan, B. C., Flett, J. A., Hunter, J. A., Scarf, D., \& Conner, T. S. (2018). Fear of missing out (FoMO): The relationship between FoMO, alcohol use, and alcohol-related consequences in college students. Journal of Psychiatry and Brain Functions, 2 (1), 9. https://doi.org/10.7243/20553447-2-9

51. Suryaningsih, I. B. (2020). Hedonic shopping mediation on impulse buying determinants. Journal of Management and Business, 19(1). https://doi.org/10.24123/jmb.v19i1.426 
52. Wegmann, E., Oberst, U., Stodt, B., \& Brand, M. (2017). Online-specific Fear of missing out and Internet-use expectancies contribute to symptoms of Internet-communication disorder. Addictive Behaviors Reports, 5, 33-42. https://doi.org/10.1016/j.abrep.2017.04.001

53. Wiranata, A. T., \& Hananto, A. (2020). Do Website Quality, Fashion Consciousness, and Sales Promotion Increase Impulse Buying Behavior of E-Commerce Buyers? Indonesian Journal of Business and Entrepreneurship, 6 (1), 74. https://doi.org/10.17358/ijbe.6.1.74

54. Witte, K., \& Allen, M. (2000). A meta-analysis of Fear appeals: Implications for effective public health campaigns. Health Education and Behavior, 27 (5), 591-615. https://doi. org/10.1177/109019810002700506

55. Zafar, A. U., Qiu, J., Li, Y., Wang, J., \& Shahzad, M. (2019). The impact of social media celebrities' posts and contextual interactions on impulse buying in social commerce. Computers in Human Behavior. In press. https://doi.org/10.1016/j.chb.2019.106178

56. Zhang, M., Qin, F., Wang, G. A., \& Luo, C. (2019). The impact of live video streaming on online purchase intention. Service Industries Journal, 40 (9-10), 656-681. https://doi.org/10.1080 /02642069.2019.1576642

\section{Contact information}

Prof. Rizwan Raheem Abmed, Ph.D.

Indus University

Faculty of Management Sciences

Pakistan

E-mail: rizwanraheemahmed@gmail.com

ORCID: 0000-0001-5844-5502

Prof. Dalia Streimikiene, Ph.D. (Corresponding author)

Ton Duc Thang University

Faculty of Environment and Labour Safety,

E-mail:dalia.streimikiene@tdtu.edu.vn

Vietnam

ORCID: 0000-0002-3247-9912

Prof. Jo-Ann Rolle,Ph.D.

The City University of New York (CUNY)

US School of Business Medgar Evers College

USA

E-mail:jrolle@mec.cuny.edu

Assoc. Prof. Pham Anb Duc, PhD

Ton Duc Thang University

Faculty of Environment and Labour Safety

Vietnam

E-mail:phamanbduc@tdtu.edu.vn 